\title{
Short- and medium-term response to storms on three Mediterranean coarse-grained beaches
}

\author{
Edoardo Grottoli ${ }^{\mathrm{a}, *}$, Duccio Bertoni ${ }^{\mathrm{b}}$, Paolo Ciavola ${ }^{\mathrm{a}}$ \\ a Department of Physics and Earth Sciences, University of Ferrara, Ferrara, Italy \\ b Department of Earth Sciences, University of Pisa, Pisa, Italy
}

\section{A R T I C L E I N F O}

\section{Article history:}

Received 28 February 2017

Received in revised form 4 August 2017

Accepted 5 August 2017

Available online 07 August 2017

\section{Keywords:}

Beach recovery

Shoreline rotation

Beach nourishment

Mixed beach

Storm impact

Microtidal beach

\begin{abstract}
A B S T R A C T
The storm response of three Italian coarse-grained beaches was investigated to better understand the morphodynamics of coarse-clastic beaches in a microtidal context. Two of the studied sites are located on the eastern side of the country (Portonovo and Sirolo) and the third one (Marina di Pisa) is on the western side. Portonovo and Sirolo are mixed sand and gravel beaches where the storms approach from two main directions, SE and NE. Marina di Pisa is a coarse-grained, gravel-dominated beach, exposed to storms driven by SW winds. Gravel nourishments were undertaken in recent years on the three sites. Beach topography was monitored measuring the same network of cross sections at a monthly (i.e. short-term) to seasonal frequency (i.e. mediumterm). Geomorphic changes were examined before and after storm occurrences by means of profile analyses and shoreline position evaluations. The beach orientation and the influence of hard structures are the main factors controlling the transport and accumulation of significant amount of sediments and the consequent high variability of beach morphology over the medium-term. For Marina di Pisa, storms tend to accumulate material towards the upper part of the beach with no shoreline rotation and no chance to recover the initial configuration. Sirolo and Portonovo showed a similar behaviour that is more typical of pocket beaches. Both beaches show shoreline rotation after storms in a clockwise or counter-clockwise direction according to the incoming wave direction. The wider and longer beach at Sirolo allows the accumulation of a thin layer of sediment during storms, rather than at Portonovo where, given its longshore and landward boundaries, the beach material tends to accumulate in greater thickness. After storms, Sirolo and especially Portonovo can quickly recover the initial beach configuration, as soon as another storm of comparable energy approaches from the opposite direction of the previous one. Large morphological variations after the storm on mixed sand and gravel beaches do not necessarily mean a slower recovery of surface topography and shoreline position. Considering that all the three beaches were recently nourished with gravel, it emerged that the differences between the nourishment and the native material, in terms of size and composition, seem to have an important influence on the dynamics of the sediment stock. Considering that recent studies have remarked the high abrasion rate of gravel, further understanding of the evolution of nourishment material with time is needed. The peculiar behaviour of gravel material artificially added to an originally sandy beach suggests the need to modify the widely used classification of Jennings and Shulmeister (2002) adding a fourth additional beach typology, which could represent human-altered beaches.
\end{abstract}

(c) 2017 Elsevier B.V. All rights reserved.

\section{Introduction}

High energy events emphasize beach erosion effects, sometimes leading to huge volume deficits that are not balanced by recovery under fair-weather conditions, especially because the recovery time, which is generally defined as the calm period between two consecutive storms, is always shorter than the time needed for a complete recovery (Sénéchal et al., 2017). Beach recovery at times can be very rapid but in the case of exceptionally high-energy events such times can be

\footnotetext{
* Corresponding author.

E-mail address: grtdrd@unife.it (E. Grottoli).
}

multidecadal. However, on some occasions storms can counteract the loss, triggering a recovery trend (Scott et al., 2016). Beach erosion occurs in every coastal setting, regardless of the average level of wave energy that affects a beach or the grain-size that constitutes its sediment volume. Intuitively, sandy beaches are the most affected because these sediment fractions are subjected to entrainment and intense displacement at lower energy states than coarser sediments. However, recent studies have evidenced that gravel also moves significantly when wave motion is low (Bertoni et al., 2013; Grottoli et al., 2015), leading to a secondary factor responsible for volume reduction on coarse-clastic beaches, through a rapid sediment abrasion (Bertoni et al., 2012; Chen and Stephenson, 2015; Bertoni et al., 2016). Thus, there is a growing interest 
in the understanding of storm response on mixed and coarse-grained beaches due to the increased use of coarse sediments as nourishment material (Bramato et al., 2012). Artificial replenishments are frequently used as a form of coastal protection where natural beach feeding is inadequate to maintain the equilibrium: large volumes of sediments are added into the system providing the sediment budget with stock able to accommodate the sediment loss that occurs with time. While on the short-term the solution might be economically more sustainable than constructing hard-defences, on a longer term there may not be enough fill locally available (Maddrell, 1996). Since climate change is expected to accentuate the erosion effects in the near future (Bray and Hooke, 1997; Zhang et al., 2004; Dickson et al., 2007), the need to artificially feed beaches is likely to increase. In this scenario, gravel is used more and more often as beach fill, based on its higher stability in comparison to finer sediments (Masselink and Hughes, 2003; Buscombe and Masselink, 2006; Nordstrom et al., 2008), on some occasions replacing the native sand (Bertoni and Sarti, 2011a). In the last decade several papers on coarse-grained beach morphodynamics have been produced (e.g. Austin and Buscombe, 2008; Bluck, 2011; Dickson et al., 2011; Poate et al., 2013; Hay et al., 2014; McCall et al., 2015) but still there are significant gaps to fill in order to considerably improve the understanding of this type of environment.

The morphological impact of storms on beaches has been widely analyzed in the oceanic context and on exposed sandy coasts (Morton and Sallenger, 2003; Ivamy and Kench, 2006; Masselink and van Heteren, 2014; Scott et al., 2016). In the Mediterranean area, much of which is characterized by the presence of mountains located at a short distance from the sea, mixed and coarse-clastic beaches are quite common (Poate et al., 2013) and on some islands may constitute one of the main beach typologies (Sammut et al., 2017). The response of these kind of beaches to storms has started to be investigated only recently (Naylor et al., 2017) and only with respect to a few aspects: the adjustments of nearshore topography and shoreline variation (Backstrom et al., 2008; Bramato et al., 2012; Turki et al., 2013; Harley et al., 2014), the role of nearshore and swash zone hydrodynamics in beach recovery (Ivamy and Kench, 2006; Bergillos et al., 2016), the transport of gravel generated by storms (Han et al., 2017; Bertoni et al., 2010), the sediment and geomorphic variations after different kinds of storms (Roberts et al., 2013) and the first attempts to model the coarse-clastic beach response to storms (McCall et al., 2014, 2015; Almeida et al., 2017). Usually the authors tend to highlight the relative shortage of studies of gravel beaches if compared to the sandy ones, but the storm response of coarse-grained beaches is in particular need of in-depth analyses. Masselink and van Heteren (2014) and Scott et al. (2016) highlighted the need for high-resolution and comprehensive decadal records of beach response to storms as pre-requisite to achieve a better understanding of beach response to climate change, linking site-specific coastal settings, hydrodynamic drivers, morphological responses, and allowing the recognition of recovery- and impact-dominated phases. Few investigations on gravel beaches emphasized the role of sediment size as a key factor controlling the storm response (Bertoni et al., 2010; Poate et al., 2013). Thus, it is even more crucial to study the storm response of mixed and coarse-grained beaches where there is a large variation of sediment size that complicates the analyses.

The need of further investigations on mixed and coarse-clastic beaches is also topical to provide tools for modeling the behaviour of these natural systems (Poate et al., 2013). Modeling of gravel and mixed beaches is only at the early stages and needs several in situ analyses for model validation (McCall et al., 2015; Almeida et al., 2017). The awareness of storm impacts is more critical than in the past and the understanding of beach recovery to extreme events needs new insights to combine the preservation of natural beach evolution with a demand of a wider beach for recreational purposes due to beach occupation, as seen in the Mediterranean. That is particularly pressing on coarse-grained and mixed beaches, where the need to predict storm impact and recovery is much more vital considering that finding suitable sediment to refill the beach is never an easy task. Indeed, while on the shorelines of shelf seas like the North Sea, glaciations have left large deposits of suitable sand and gravel on the seabed, in southern European seas there is no gravel on the continental shelf, thus the only possible source is either relict alluvial deposits along the river's floodplain or crushed material coming from inland quarries.

The paper examines the medium-term morphological response to storms of three coarse-grained beaches in the Mediterranean context. The objective of this work is to understand how these kinds of beaches can recover after storms of different energy and which are their characteristics having a crucial controls on beach recovery. All the three beaches have experienced nourishments with gravel material in recent years and this represents an interesting peculiarity of this study.

\section{Regional setting}

The beaches where the surveys have been carried out are located on both sides of the Italian Peninsula: Marina di Pisa is on the western side, whereas Portonovo and Sirolo are on the eastern side (Fig. 1). They were selected because of their physical characteristics, which made them perfect sites to investigate beach response after storms. Marina di Pisa is located in the central sector of Tuscany, facing the southernmost sector of the Ligurian Sea. It is a small village about $11 \mathrm{~km}$ southwest of the city of Pisa, whose sandy beaches were completely wiped out by serious erosion processes that started towards the end of the XIX century (Aminti et al., 2000; Bertoni and Sarti, 2011b). Although multiple defence schemes were adopted to protect the coastline, only hard structures, such as seawalls and breakwaters, and replenishments with pebbles led to a state of substantial equilibrium (Bertoni and Sarti, 2011a). The beach where the surveys have been realized is named Barbarossa; it is one of the above-mentioned artificial beaches built between years 2006-2008 with a twofold purpose: to prevent further retreat of the coastline and to support the local economy by allowing beach users to use the seaside during the summer. It is about $180 \mathrm{~m}$ long and 10-25 m wide; its orientation is approximately N-S. Two large rock groins border the beach at both sides, whereas a seawall constituted by massive boulders separates the backshore from a parking area (Fig. 1A). This configuration prevents any sediment exchange with the adjacent sectors of the coast. Among the three types of coarse-grained beaches conceived by the classification of Jennings and Shulmeister (2002), the beach in Marina di Pisa could be classified as a composite gravel beach based on the net separation at the step line between sand and gravel. The native sand is covered by marble pebbles and cobbles with grain size ranging from 30 to $90 \mathrm{~mm}$ and a mean diameter of $60 \mathrm{~mm}$ (Bertoni et al., 2016): the coarse fraction represents the sediment used as beach fill during the 2008 nourishment project. Sediment characterizations of the beach were made in the following years, resulting in a mean diameter of $45 \mathrm{~mm}$ at the step zone, $20 \mathrm{~mm}$ on the fair-weather berm and $45 \mathrm{~mm}$ on the storm berm. Beach steepness is particularly high on the backshore, where it reaches 19\% (Bertoni and Sarti, 2011a); seaward the steepness decreases up to the typical values of this sector of the Ligurian Sea (1\%; Cipriani et al., 2001). The tidal regime is semi-diurnal; the maximum tidal range measured at spring tide is $0.4 \mathrm{~m}$ (microtidal environment). With regard to sea weather conditions, the typical wave approach direction is SW. The wave height is between 0.25 and $2 \mathrm{~m}$ for more than $60 \%$ of the time, while it is lower than $0.25 \mathrm{~m}$ just for $5 \%$ of the time; the remaining $35 \%$ wave height is higher than $2 \mathrm{~m}$ (Bertoni et al., 2013). Major storms usually come from SW (Bertoni et al., 2013). The littoral drift is southwards trending along this sector of the Tuscany coast (Gandolfi and Paganelli, 1975; Anfuso et al., 2011).

Portonovo and Sirolo beaches are located along the coast of the Marche region, in the central sector of the Adriatic Sea; in particular, they are located in the northern and central portions of the Conero Headland, an almost $600 \mathrm{~m}$ high rocky promontory that interrupts the linearity of the Adriatic coast (Fig. 1). Portonovo beach is approximately 


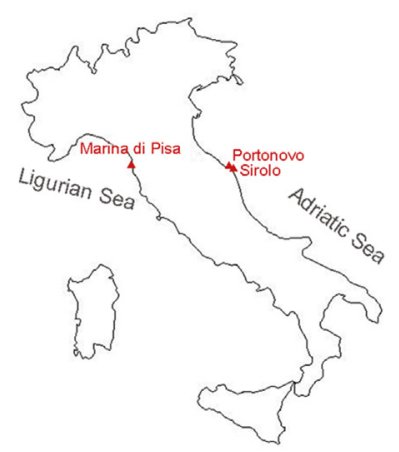

Italy: western side

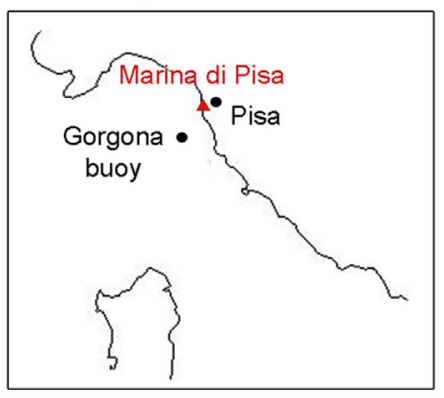

Italy: eastern side

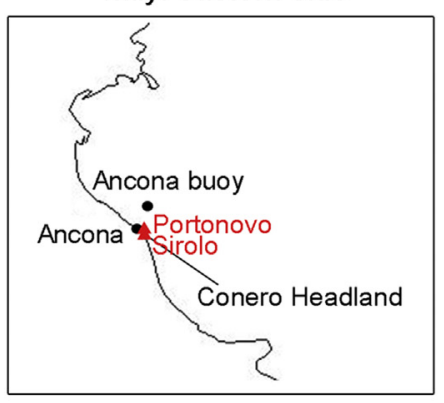

Profiles
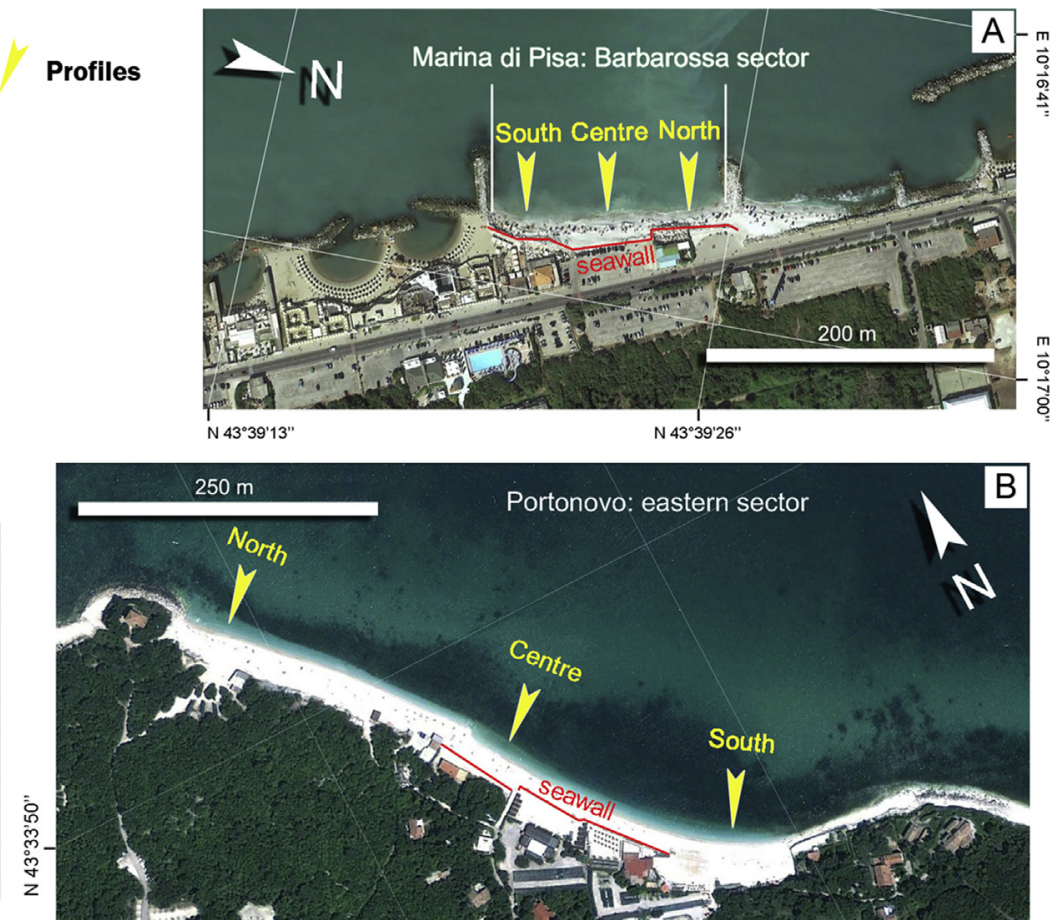

$\mathrm{N} 43.3913$

N $43^{\circ} 39^{\prime} 26^{\prime \prime}$

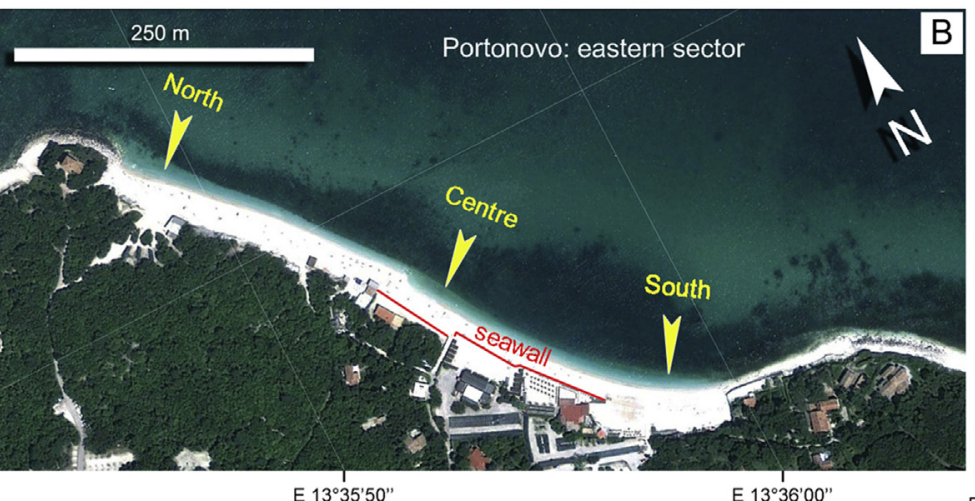

E $13^{\circ} 35^{\prime} 50^{\prime \prime}$

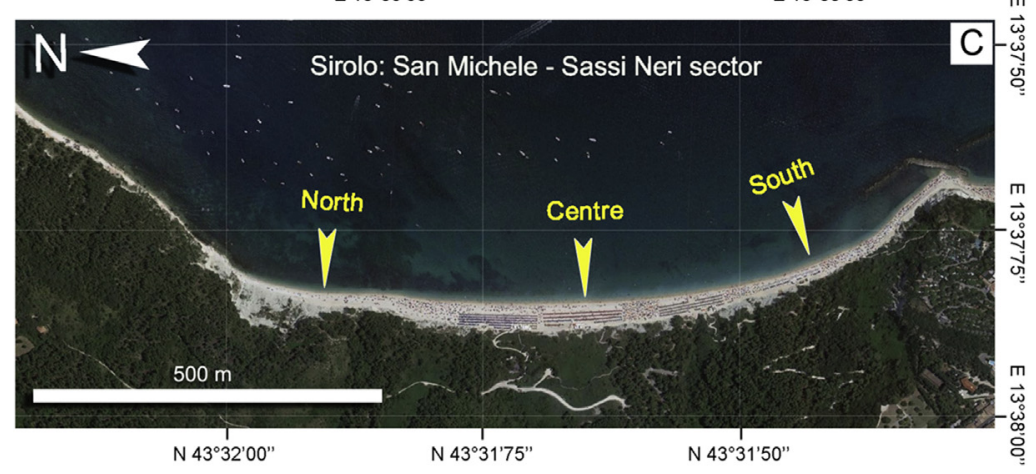

Fig. 1. Beach location and reference profiles for each site: (A) Marina di Pisa; (B) Portonovo; (C) Sirolo.

$500 \mathrm{~m}$ long and 20 to $60 \mathrm{~m}$ wide; it is bounded at both edges by seawalls made of boulders that were built to protect historical buildings. No sediment exchange with the adjacent sectors of the coast is estimated to happen due to the presence of these hard structures (Fig. 1B). No river mouths are present along the beach, which is basically formed by the deposition of sediments eroded from the cliff that backs-up the beach. The beach face typically slopes 0.18 , whereas the seabed seaward of the step is approximately 0.01 , as normally seen on Adriatic shores. The prevalent sediment fraction is constituted by pebbles (4-64 mm in diameter), but the beach is poorly-sorted, ranging from medium sand to cobbles (Grottoli et al., 2015). Based on recurring erosion processes that this sector of coast experienced during the last decades, beach fills have been realized to artificially feed the eroding beaches of Portonovo area between 2006 and 2011 for a total amount of $18,500 \mathrm{~m}^{3}$ (personal communication by officers Stefano Parlani and Giorgio Filomena of the Regione Marche) even though the precise quantity released at our study site is unknown. Limestone pebbles (grain size ranging from 4 to $100 \mathrm{~mm}$ with a mean diameter of $20 \mathrm{~mm}$ ) from alluvial deposits of nearby areas were used as nourishment materials to preserve the integrity of the beach, as native sediments are made of marl and limestone. Sediment characterizations of the beach undertaken in recent years (Grottoli, 2015) found a mean diameter of $30 \mathrm{~mm}$ on the step zone, $6 \mathrm{~mm}$ on the fair weather berm and $7 \mathrm{~mm}$ on the storm berm. Sirolo beach, named San Michele - Sassi Neri, is a naturally embayed pocket beach about $1.2 \mathrm{~km}$ long and 20 to $60 \mathrm{~m}$ wide. As in Portonovo, in terms of sedimentary budget the system is closed in the longshore directions due to a groin that limits the beach at its southern end and by a rocky cliff delimiting the beach at the northern end (Fig. 1C). Sirolo beach is naturally fed by cliff erosion as no rivers flow within it: the prevalent grain-size is gravel of about 2 to $32 \mathrm{~mm}$ in diameter (granules and pebbles), sediments are limestones and marls and range in size from medium sand to cobble. The beach face typically slopes at 0.16 whereas the seabed seaward of the step, as in Portonovo, is approximately 0.01 . Between 2009 and 2011, 156,000 $\mathrm{m}^{3}$ of alluvial gravel ( $90 \%$ limestone, with grain size ranging from 6 to $12 \mathrm{~mm}$ with a mean diameter of $8 \mathrm{~mm}$ ) were brought to the beach to mitigate long-term erosion trends (Regione Marche, 2005; Harley et al., 2014). Sediment characterization done in recent years in Sirolo beach (Molinelli, 2014) found that the mean diameter on the step zone is $8 \mathrm{~mm}$, and mean diameters of 6 and $4 \mathrm{~mm}$ were measured on the fair-weather berm and on the storm berm, respectively. According to the Jennings and Shulmeister (2002) classification, Portonovo and Sirolo can be defined as two mixed sand and gravel beaches (MSG) based on the intermixing between sand and gravel. The average tidal range at spring tide is $0.4 \mathrm{~m}$ (Colantoni et al., 2003). NE and SE are the dominant wind directions, which are in accordance with storm event 
Table 1

Survey data for the three sites.

\begin{tabular}{|c|c|c|c|}
\hline & Marina di Pisa & Portonovo & Sirolo \\
\hline N. profiles & 11 & 50 & 18 \\
\hline Profile spacing & $15 \mathrm{~m}$ & $10 \mathrm{~m}$ & $70 \mathrm{~m}$ \\
\hline \multirow[t]{3}{*}{ Surveys } & Nov 2013 (initial or pre-storm) & Oct 2012 (initial or pre-storm) & Mar 2012 (initial or pre-storm) \\
\hline & Dec 2013 (intermediate or post-storm) & Nov 2012 (intermediate or post-storm) & Apr 2012 (intermediate or post-storm) \\
\hline & Feb 2014 (final or recovery) & Dec 2012 (final or recovery) & Oct 2012 (final or recovery) \\
\hline
\end{tabular}

directions. Wave height is between $0.25 \mathrm{~m}$ and $2 \mathrm{~m}$ for $80 \%$ of the time, while it is lower than $0.25 \mathrm{~m}$ for $10 \%$ of the time; the remaining $10 \%$ wave height is higher than $2 \mathrm{~m}$ (Grottoli et al., 2015). The littoral drift is northward-trending along this sector of the Adriatic Sea coast (Regione Marche, 2005).

\section{Materials and methods}

\subsection{Offshore wave data and storm characterization}

In Portonovo and Sirolo the wave data were recorded by the Ancona offshore wave buoy (Fig. 1) installed and maintained by ISPRA (ISPRA Servizio Mareografico "Rete Ondametrica Nazionale", Bencivenga et al., 2012). For the site of Marina di Pisa wave data were collected by the offshore buoy located nearby Gorgona Island (Fig. 1) and provided by the hydrological office of Regione Toscana (CFR-Regione Toscana). Following Armaroli et al. (2012), the storm events were identified considering a significant wave height greater than $1.5 \mathrm{~m}$ that lasted for at least six consecutive hours. According to the previous authors two storms are considered separate if the significant wave height decays below that threshold for three or more consecutive hours. For each storm the severity class was also calculated following the scale of Mendoza et al. (2011), which is based on the definition of the storm energy by Dolan and Davis (1992). The authors define the energy content of each storm as the time integral of the squared significant wave height measured during the storm event:

$E=\int_{t 1}^{t 2} H_{s}^{2} d t$

where $t_{1}$ and $t_{2}$ are the beginning and the end of the storm (hours) and $\mathrm{H}_{\mathrm{s}}$ is the significant wave height. As stated by Mendoza et al. (2011), the use of a single wave height value to characterize the storm (e.g. stormaveraged $\mathrm{H}_{\mathrm{s}}$ or $\mathrm{H}_{\mathrm{s}}$ at the peak of the storm) might result in an under- or over-estimation of the actual wave storm energy. Because of the lack of wave records provided by the offshore buoys during some periods, $\mathrm{H}_{\mathrm{s}}$ at the peak of the storm was used to classify each storm event.

\subsection{Beach topography}

The morphological evolution of the three beaches was monitored by means of an RTK-DGPS device (Trimble R6) with an accuracy of $\pm 2 \mathrm{~cm}$. For each site a topographic network was used in three different surveys, covering a period of several months (i.e. medium-term). For each site it has been acquired an initial (or pre-storm), an intermediate (or poststorm) and a final (or recovery) beach configuration (Table 1).

\subsection{Shoreline analyses}

The shoreline variation was computed using the ArcGIS tool DSAS (Digital Shoreline Analysis System) created by Thieler et al. (2009). The DSAS tool was applied on 5-m spaced profiles for each site using an uncertainty of $0.5 \mathrm{~m}$. Shoreline digitization from field surveys was possible using specific query expressions in ArcGIS which are able to select, among the measured points, elevation values within $\pm 0.2 \mathrm{~m}$ interval. Elevation measured by RTK-DGPS was referred to the mean sea-level position, which for Italy corresponds to the datum recorded in Genoa. Applying the GIS procedure described above, the shoreline (i.e. the $0 \mathrm{~m}$ value) can be defined as the mid-point of this strip of elevation values. The NSM (Net Shoreline Movement) tool of DSAS was used to compare from one survey to another and from the first (initial or prestorm survey) to the last (final or recovery survey). The Net Shoreline Movement (NSM) tool computes the distance between the youngest and the oldest shoreline (Thieler et al., 2009).

\section{Results}

\subsection{Offshore wave data}

Within the survey period carried out at Marina di Pisa, twelve storm events were identified. After the first topographic survey, a severe storm (according to the storm classification of Mendoza et al., 2011) hit the coast from WSW with a maximum $\mathrm{H}_{\mathrm{s}}$ of $4.1 \mathrm{~m}$ and $52 \mathrm{~h}$ of duration (event no. 2; Table 2; Fig. 2). This was the most powerful storm which affected Marina di Pisa during the survey period. The second topographic survey was realized after another storm of considerable energy: a storm of moderate class approaching from WSW, which lasted for $27 \mathrm{~h}$ with a maximum $\mathrm{H}_{\mathrm{s}}$ of $3.3 \mathrm{~m}$ (event no. 3; Table 2; Fig. 2). The remaining nine weak storms that characterized the period between the second and third survey are similar in terms of wave characteristics and duration. All the storms that occurred in the monitoring period came from the SW directional sectors (Table 2; Fig. 2).

At Portonovo twelve storm events were recognized during the survey period. According to Mendoza et al. (2011) storm classification, a severe and a significant storm (III and IV category, respectively) occurred before the intermediate survey. The first one (storm no. 3, Fig. 3; Table 3) was characterized by a $\mathrm{H}_{\mathrm{s}}$ of $5.2 \mathrm{~m}$ at his peak and a duration of $30.5 \mathrm{~h}$. Concerning the $\mathrm{H}_{\mathrm{s}}$ and the total energy released, this was the most powerful storm recorded across all the three sites. The second storm (event no. 5, Fig. 3; Table 3) lasted $38 \mathrm{~h}$ with a maximum $\mathrm{H}_{\mathrm{s}}$ of $4 \mathrm{~m}$. Both storms approached the coast from ESE (Sirocco wind). In the period between the second and the third survey, other seven storms

Table 2

Characteristics of the storm events occurred within the survey period in Marina di Pisa.

\begin{tabular}{llllllll}
\hline $\begin{array}{l}\text { Event } \\
\text { no. }\end{array}$ & Start date & $\begin{array}{l}\text { Duration } \\
(\mathrm{h})\end{array}$ & $\begin{array}{l}\mathrm{H}_{\mathrm{s}} \\
\max \\
(\mathrm{m})\end{array}$ & $\begin{array}{l}\text { Dir } \\
\text { at } \\
\text { peak }\end{array}$ & $\begin{array}{l}\mathrm{T}_{\mathrm{p}} \\
\max \\
(\mathrm{s})\end{array}$ & $\begin{array}{l}\text { Total } \\
\text { energy } \\
\left(\mathrm{m}^{2} \mathrm{~h}\right)\end{array}$ & $\begin{array}{l}\text { Storm class } \\
\text { (Mendoza } \\
\text { et al., 2011) }\end{array}$ \\
\hline 1 & $15 / 11 / 2013$ & 17 & 3.2 & WSW & 10.3 & 170 & I (weak) \\
2 & $20 / 11 / 2013$ & 52 & 4.1 & WSW & 9.9 & 896 & IV (severe) \\
3 & $26 / 12 / 2013$ & 27 & 3.3 & WSW & 11.5 & 290 & II (moderate) \\
4 & $05 / 01 / 2014$ & 18 & 2.1 & WSW & 11 & 79 & I (weak) \\
5 & $14 / 01 / 2014$ & 25 & 2.5 & WSW & 7.9 & 169 & I (weak) \\
6 & $17 / 01 / 2014$ & 21 & 2.2 & SSW & 6.8 & 98 & I (weak) \\
7 & $18 / 01 / 2014$ & 19 & 2 & SSW & 8.3 & 74 & I (weak) \\
8 & $30 / 01 / 2014$ & 27 & 2.6 & SSW & 8.8 & 180 & I (weak) \\
9 & $05 / 02 / 2014$ & 9 & 2.5 & SSW & 7.2 & 58 & I (weak) \\
10 & $07 / 02 / 2014$ & 10 & 2 & SSW & 6.6 & 38 & I (weak) \\
11 & $08 / 02 / 2014$ & 23 & 2.5 & SW & 7.5 & 145 & I (weak) \\
12 & $10 / 02 / 2014$ & 25 & 2.6 & SSW & 8.8 & 174 & I (weak)
\end{tabular}




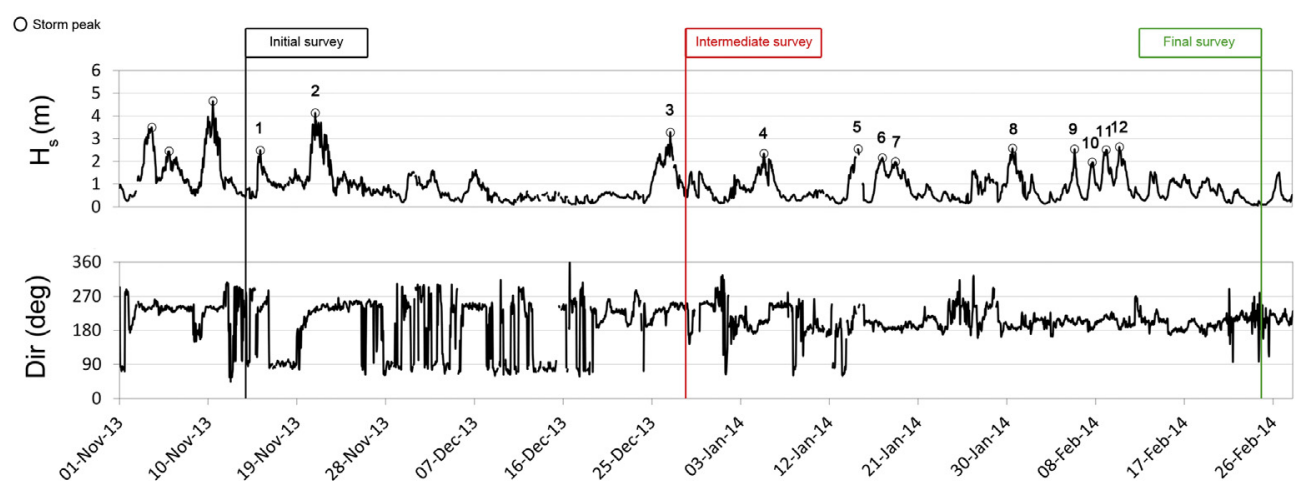

Time (dd-mmm-yy)

Fig. 2. Wave data for Marina di Pisa recorded by the local offshore buoy. Significant wave height and direction are represented throughout the survey period.

hit Portonovo beach. Two severe storms from different directions hit the coast, one approaching from ESE (event no. 7, Fig. 3; Table 3) and the other one driven by ENE (Bora wind; Fig. 3; Table 3). The storm event no. 7, with $66.5 \mathrm{~h}$ of duration, was the longest event identified in the whole dataset (Table 3 ). Another storm with significant duration but lower intensity ( $50.5 \mathrm{~h}$ and $2.4 \mathrm{~m}$ of $\mathrm{H}_{\mathrm{s}}$ at peak; Fig. 3; Table 3) was recorded just before the final survey realized in Portonovo.

At Sirolo, since the monitoring period extended from spring to the early autumn, storms with extreme energy content were not observed. Five weak storms, quite similar in wave energy and duration, occurred between the first and the second topographic survey (Fig. 4; Table 4). The approaching direction of wave storm changed continuously from the NE to the SE directional sectors and vice-versa. Three storms occurred in the period between the second and the third topographic survey. According to the Mendoza et al. (2011) storm classification, two of them were classified as moderate severity (event nos. 6 and 7) and both approached from $\mathrm{N}$ direction (Fig. 4; Table 4). A fair weather period longer than four months, with basically no events, separated those storms from the last topographic survey (Fig. 4).

\subsection{Beach profile results}

With regard to the topographic surveys, beach profiles at Marina di Pisa underwent comparable modifications in comparison to the Adriatic Sea sites (Fig. 5). The effects of the storm no. 2 (Fig. 2; Table 2) resulted in a large accumulation of sediments on the upper backshore, especially in the central and northern sectors of the beach. In addition, the beach step became more pronounced after this high-energy event (Fig. 5). In the following months the configuration of the beach did not experience further major modifications: beach width did not vary considerably, beach slope decrease was limited only to the upper portion of the backshore. Volume loss was observed on the southern profile, where the beach surface elevation decreased of about $0.5 \mathrm{~m}$ relative to the previous configuration. Portonovo beach experienced significant topographic variations during the time frame of the surveys. Storm event no. 3 (Fig. 3; Table 3) generated a huge sediment transfer northwards. In the southern sector, scouring in the swash zone and lower backshore led to the formation of an erosive scarp. Here, the central and lower portions of the profile were reduced in elevation by 1-1.5 $\mathrm{m}$ and a profile retreat of approximately $15 \mathrm{~m}$ in comparison to the initial configuration was observed (Fig. 5). Conversely, the central and northern sectors of the beach experienced a substantial accretion along with an increase in elevation. As a matter of fact, beach surface elevation of the northern sector was about 1-2 m higher than before (Fig. 5). After the storm, the beach profile returned to a configuration similar to that of the initial situation: the only difference was a gentler steepness of the backshore, which led to a general widening of the beach. The final beach configuration was generated by another high-energy event comparable to the October/November storm $\left(\mathrm{H}_{\mathrm{s}}\right.$ peak of $\left.4.4 \mathrm{~m}\right)$ except for the direction: NNE as opposed to ESE (event no. 10, Fig. 3, Table 3). A similar behaviour was experienced at Sirolo. Despite the weakness of the five storms that occurred between the initial and the intermediate survey, sediments were clearly transported from $\mathrm{N}$ to $\mathrm{S}$. As a matter of fact the beach surface in the northern compartment became $1 \mathrm{~m}$ lower over this period (Fig. 5). The final beach configuration in Sirolo was generated by the combination of two storms occurred in May 2012 (event nos. 6 and 7, Fig. 4, Table 4) and a period of fair weather during the summer that produced a general accretion of the beach especially at its southern end. The central portion of the beach resulted to be $1 \mathrm{~m}$ lower after this period (Fig. 5).

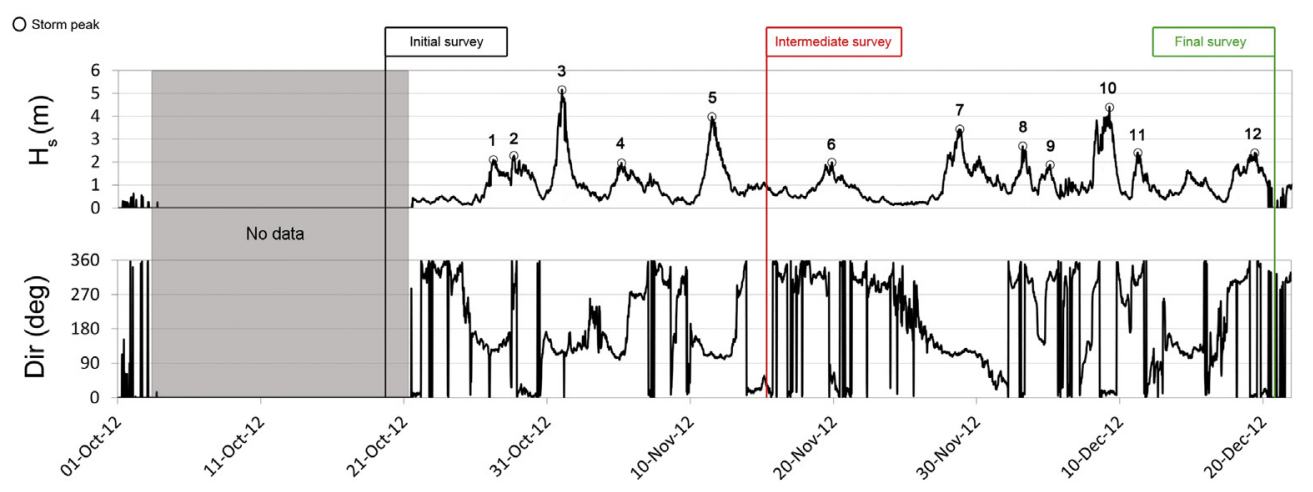

Time (dd-mmm-yy)

Fig. 3. Wave data for Portonovo recorded by the local offshore buoy. Significant wave height and direction are represented throughout the survey period. 
Table 3

Characteristics of the storm events occurred within the survey period in Portonovo.

\begin{tabular}{llllllll}
\hline $\begin{array}{l}\text { Event } \\
\text { no. }\end{array}$ & Start date & $\begin{array}{l}\text { Duration } \\
(\mathrm{h})\end{array}$ & $\begin{array}{l}\mathrm{H}_{\mathrm{s}} \\
\mathrm{max} \\
(\mathrm{m})\end{array}$ & $\begin{array}{l}\text { Dir } \\
\text { at } \\
\text { peak }\end{array}$ & $\begin{array}{l}\mathrm{T}_{\mathrm{p}} \\
\text { max } \\
(\mathrm{s})\end{array}$ & $\begin{array}{l}\text { Total } \\
\text { energy } \\
\left(\mathrm{m}^{2} \mathrm{~h}\right)\end{array}$ & $\begin{array}{l}\text { Storm class } \\
\text { (Mendoza } \\
\text { et al., 2011) }\end{array}$ \\
\hline 1 & $26 / 10 / 2012$ & 15.5 & 2.1 & ESE & 5.7 & 68 & I (weak) \\
2 & $28 / 10 / 2012$ & 28.5 & 2.3 & NNE & 5.4 & 148 & I (weak) \\
3 & $31 / 10 / 2012$ & 30.5 & 5.2 & ESE & 7.9 & 812 & IV (severe) \\
4 & $04 / 11 / 2012$ & 13 & 2 & ESE & 5.3 & 50 & I (weak) \\
5 & $10 / 11 / 2012$ & 38 & 4 & ESE & 7.2 & 602 & III (significant) \\
6 & $19 / 11 / 2012$ & 16 & 2 & NE & 4.3 & 63 & I (weak) \\
7 & $27 / 11 / 2012$ & 66.5 & 3.4 & ESE & 7 & 782 & IV (severe) \\
8 & $03 / 12 / 2012$ & 16.5 & 2.7 & N & 5.3 & 120 & I (weak) \\
9 & $05 / 12 / 2012$ & 16.5 & 1.9 & NW & 4.5 & 58 & I (weak) \\
10 & $08 / 12 / 2012$ & 39 & 4.4 & NNE & 6.5 & 755 & IV (severe) \\
11 & $11 / 12 / 2012$ & 11 & 2.4 & WNW & 5 & 64 & I (weak) \\
12 & $17 / 12 / 2012$ & 50.5 & 2.4 & N & 5 & 291 & II (moderate) \\
\hline
\end{tabular}

\subsection{Shoreline analysis results}

At Marina di Pisa the transition from the initial to intermediate stage manifested a beach erosion in the southern zone of about $4 \mathrm{~m}$ as peak value and $1.5 \mathrm{~m}$ as mean value for the whole beach (Fig. 6 A1, B1) due to the biggest event (event no. 2, Fig. 2, Table 2). No particular variations occurred in the northern part (Fig. 6 A1, B1). During the period between the intermediate and the final survey, nine weaker storms hit the beach attaining the initial configuration: in this period, the shoreline retreated on average an additional $1 \mathrm{~m}$ (Fig. $6 \mathrm{C1}$, D1). On the whole, the cumulative shoreline variation at Marina di Pisa shows an average erosion of $2.5 \mathrm{~m}$ with peak values of $5.5 \mathrm{~m}$ measured in the southern and central area (Fig. 6 E1, F1).

Portonovo experienced the largest shoreline variation among the three beaches. During the initial and the intermediate period the shoreline underwent a counter-clockwise rotation due to events nos. 3 and 5 from ESE (Fig. 3, Table 3) with the pivotal point located between the central and the southern part of the beach. In this period an erosion peak value of $16 \mathrm{~m}$ was recorded in the southern zone (mean value $13 \mathrm{~m}$ ) and an accretional peak value of $11 \mathrm{~m}$ was measured in the central/northern area (mean value 6 m; Fig. 6 A2, B2). Between the intermediate and the final stages a mirror situation was generated by event no. 10 driven from NNE (Fig. 3, Table 3): a clockwise rotation with the same pivotal point took place (Fig. 6 C2, D2). Quite similar storms produced comparable deposition/erosion values: erosional peak value of $16 \mathrm{~m}$ in the central/northern zone (mean value $10 \mathrm{~m}$ ); accretional peak value of $12 \mathrm{~m}$ in the southern area (mean value $5 \mathrm{~m}$; Fig. $6 \mathrm{C} 2$, D2). The cumulative variation highlights a maximum shoreline retreat of $10 \mathrm{~m}$ in the southern part and a maximum shoreline accretion of $6 \mathrm{~m}$ in the central area (Fig. 6 E2, F2).
At Sirolo the period between the initial and the intermediate survey was characterized by a general shoreline retreat of $4 \mathrm{~m}$ on average (Fig. 6 A3, B3) caused by weak storms from opposite directions (Fig. 4, Table 4). In the period between the intermediate and the final stage the southern part of the beach was characterized by an accretion of $5 \mathrm{~m}$ as average, with a peak of $10 \mathrm{~m}$ (Fig. 6 C3, D3) due to events nos. 6 and 7 driven from the $\mathrm{N}$ direction (Fig. 4, Table 4). The complete surveying period resulted in a deposition of $3 \mathrm{~m}$ as mean value in the southern portion of the beach and an average retreat of $3 \mathrm{~m}$ in the central/northern area (Fig. 6 E3, F3).

\section{Discussion}

Storm events at Marina di Pisa come from the unique direction, which is the SW sector. Storm direction is almost perpendicular to the beach orientation (Fig. 1A), that is one of the main reasons why the beach experienced a shoreline retreat over almost the entire beach length and a sediment transport towards the upper part of the beach profile. Nevertheless, the shoreline retreat was greater in the southern portion (Fig. 6 A1, C1, F1) while the sediment accumulation was thicker in the northern part (Fig. 5); this process did not produce a counterclockwise rotation of the shoreline as might be expected: the groins and the hard structures limiting the beach remove the necessary space for the natural sediment translation. Cammelli et al. (2006), thanks to a longer survey period lasted more than one year, noted that the shoreline can realign itself towards the direction of the dominant incident wave energy as a result of the longshore transport directed southward. After the Cammelli et al. (2006) study an extra groin was built, which is the one that nowadays limits the beach to the north, thus reducing the accommodation space for shoreline readjustment. At Marina di Pisa, during the major storms (events nos. 2 and 3, Table 2; Fig. 2) sediments moved up on the beach profile (as already noted by Cammelli et al., 2006), where the presence of the buildings and of the protected parking area, that occupy part of the backshore (Fig. 1A), facilitated sediment accumulation. The tendency of an onshore migration and accretion of the storm berm was also confirmed in the study by Ellis and Cappietti (2013) by means of laboratory tests on a scale model of a nearby beach, with similar characteristics. The cited beach ("Pisa 1" in Nordstrom et al., 2008; "Cella 7" in Bertoni and Sarti, 2011a) is only one kilometer northward of the beach studied in this paper and has a submerged breakwater $60 \mathrm{~m}$ seaward of the coastline as the only distinct feature. According to Bertoni and Sarti (2011a) the behaviour of these two beaches during storms is basically the same but for the amount of the material deposited onshore by the storm waves. Despite the period from the intermediate and the final survey being characterized by weak storms (nine weak storms with $\mathrm{H}_{\mathrm{s}}$ max between 2 and $2.6 \mathrm{~m}$; Table 2), the initial beach configuration was not reached again during the period of observation. It is likely that the weaker storm

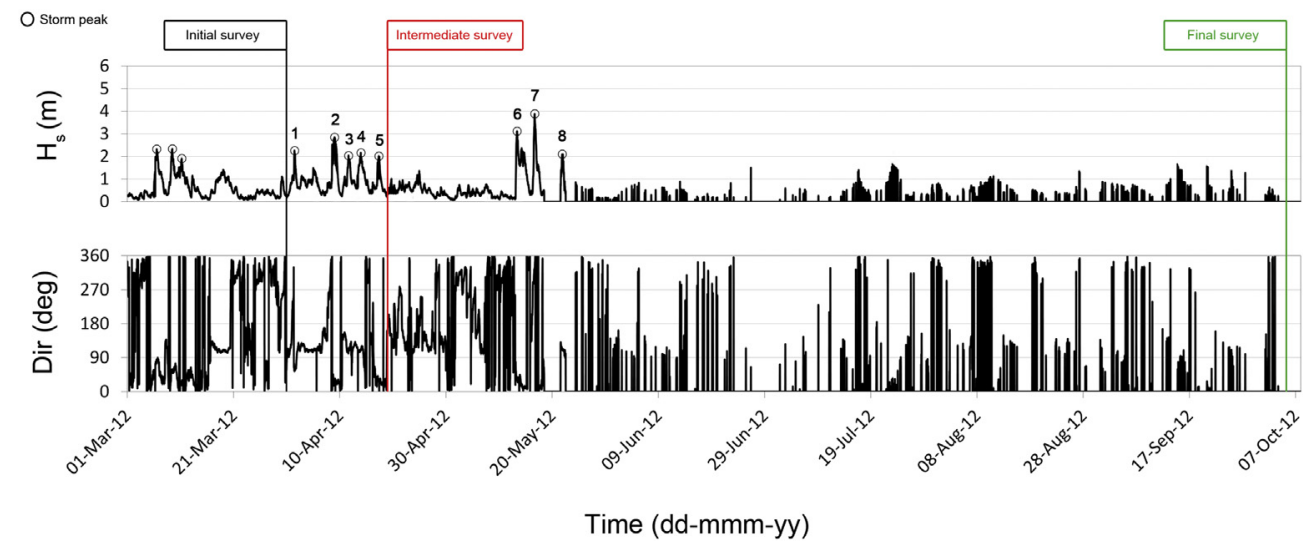

Fig. 4. Wave data for Sirolo recorded by the local offshore buoy. Significant wave height and direction are represented throughout the survey period. 
Table 4

Characteristics of the storm events occurred within the survey period in Sirolo.

\begin{tabular}{llllllll}
\hline $\begin{array}{l}\text { Event } \\
\text { no. }\end{array}$ & Start date & $\begin{array}{l}\text { Duration } \\
(\mathrm{h})\end{array}$ & $\begin{array}{l}\mathrm{H}_{\mathrm{s}} \\
\mathrm{max} \\
(\mathrm{m})\end{array}$ & $\begin{array}{l}\text { Dir } \\
\text { at } \\
\text { peak }\end{array}$ & $\begin{array}{l}\mathrm{T}_{\mathrm{p}} \\
\mathrm{max} \\
(\mathrm{s})\end{array}$ & $\begin{array}{l}\text { Total } \\
\text { energy } \\
\left(\mathrm{m}^{2} \mathrm{~h}\right)\end{array}$ & $\begin{array}{l}\text { Storm class } \\
\text { (Mendoza et al., } \\
2011)\end{array}$ \\
\hline 1 & $01 / 04 / 2012$ & 6 & 2.3 & ENE & 5 & 31 & I (weak) \\
2 & $08 / 04 / 2012$ & 24 & 2.9 & NNE & 5.5 & 195 & I (weak) \\
3 & $11 / 04 / 2012$ & 10 & 2 & ESE & 5.7 & 42 & I (weak) \\
4 & $13 / 04 / 2012$ & 17.5 & 2.2 & ESE & 5.3 & 82 & I (weak) \\
5 & $17 / 04 / 2012$ & 10 & 2 & NNE & 5.1 & 41 & I (weak) \\
6 & $13 / 05 / 2012$ & 44 & 3.1 & NNE & 5.9 & 428 & II (moderate) \\
7 & $16 / 05 / 2012$ & 22 & 3.9 & NNW & 7.1 & 333 & II (moderate) \\
8 & $21 / 05 / 2012$ & 8 & 2.1 & ESE & 5.6 & 35 & I (weak) \\
\hline
\end{tabular}

waves reached the backshore, dragging sediments towards the sea: this process produced a slope decrease in the upper backshore but without a corresponding shoreline advancement or return to the initial profile configuration. Unfortunately, the laboratory experiment done by Ellis and Cappietti (2013) did not evaluate the evolution of the beach after the storms: as a consequence, no data were provided about beach recovery. According to our survey data, the final period at Marina di Pisa was also characterized by the development of a step in the central part of the beach (Fig. 5). Poate et al. (2013) observed the same morphological behaviour with equivalent wave energy $\left(\mathrm{H}_{\mathrm{s}}=2.4-2.5 \mathrm{~m}\right)$ but longer wave periods (up to $13 \mathrm{~s}$ ), arguing that the step is developed with these kind of wave energy and acts like a stabilising feature for the upper profile, reducing the wave run-up and the swash flux power. Even though the initial (pre-storm) profile configuration was not reached again during the period of observation, the cumulative effect of weak storms with a small return period decreased the upper beach slope and built up the step in the lower profile. The important role of storm groups of average energy was already highlighted by Ferreira
(2005) on sandy open beaches. This author noticed that the cumulative effect for a number of medium energy storms could over-rule the impact of a much more energetic event. His work clearly underlined the importance of average storm groups on beach morphology and consequently on beach management. As already found by Bertoni and Sarti (2011b) over a longer monitoring period, Marina di Pisa showed evidence of wave reflection processes due to the formation of a huge and steep storm berm after high-energy events. This configuration, given also the unimodal direction of storms, cannot be compensated by milder sea state periods, and the initial profile configuration can be reached again only through human intervention by redistributing the coarse material piled by the strongest storm over the entire beach extent (Fig. 7).

Portonovo experienced the strongest storms and the most evident morphological variations among the three beaches. Due to the hard structures that compartmentalize the beach, it acts like a natural pocket beach. On these beaches shoreline rotation along with the formation of storm berms and erosive scarps frequently occur after major storms (Grottoli, 2015). The bimodal direction of storms clearly affects the beach configuration: when a storm approaches from SE (Scirocco wind), as the sediments move and accumulate in considerable thickness towards the northern beach limit by means of a clockwise shoreline rotation; vice versa, when the storm direction is NE (Bora wind) the counter-clockwise shoreline rotation produces the same depositional and erosive features in the opposite sense (Fig. $6 \mathrm{~A} 2, \mathrm{C} 2$ ). There is a mirror situation that changes after each significant storm around the pivotal point which is located in the central and southern portion of the beach. The amounts of shoreline retreat (or advance) and the accumulation (or erosion) of sediment produced by subsequent storms from opposite direction are exactly the same over the period of observation (Fig. 6 B2, D2 and Fig. 5). The balance observed at each end between erosion and accretion seems to prove that the rotation process is the result
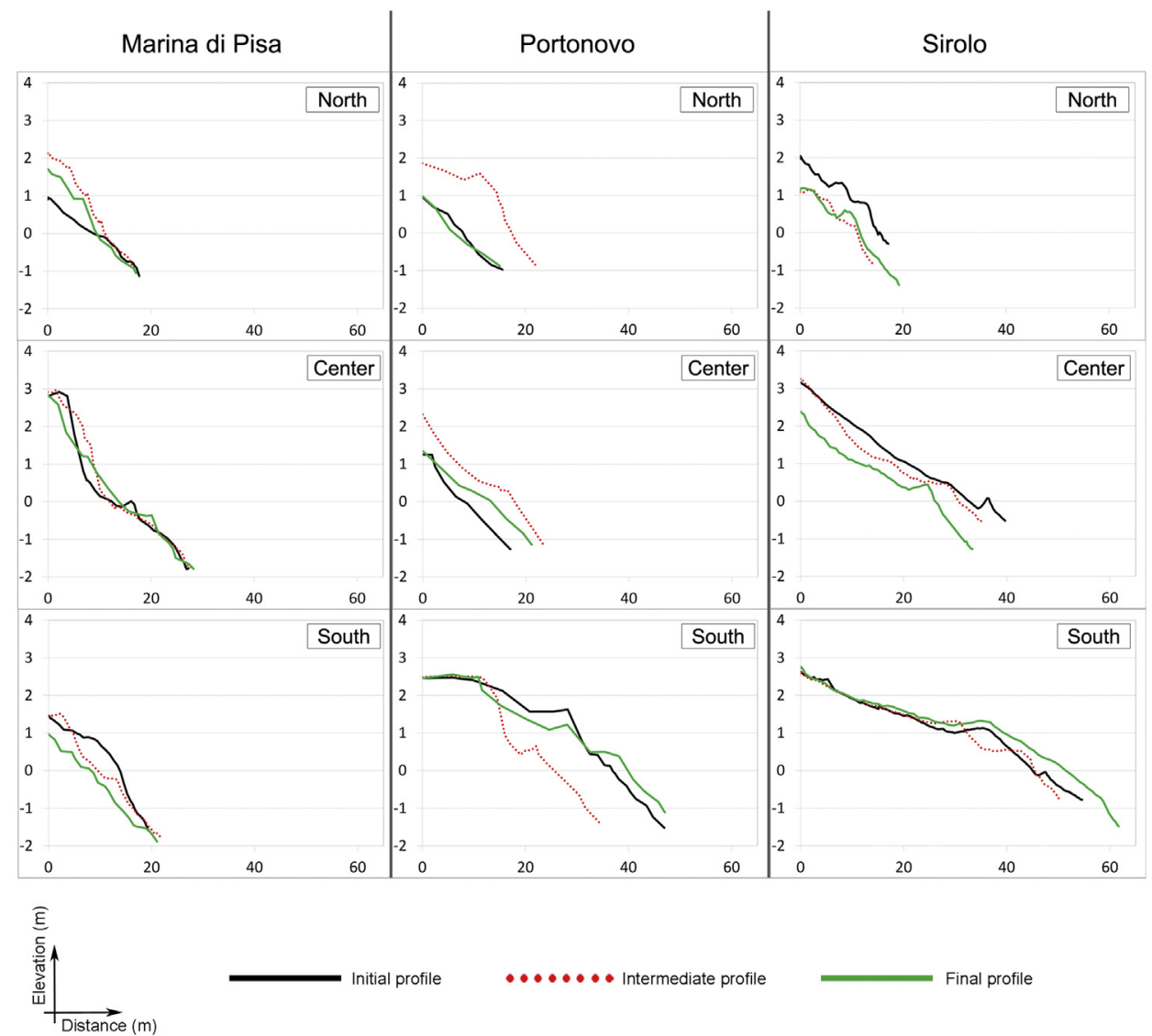

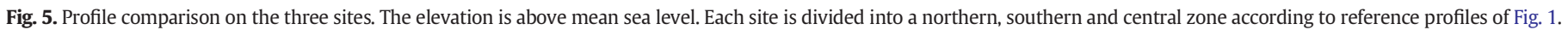


of sediment exchange between the two ends of the embayment (Short and Masselink, 1999; Harley et al., 2014). Even though the morphological changes in Portonovo were more evident, the beach here showed recovery over the medium-term. The recovery is helped by the beach orientation (NW-SE), which permits the incidence of storms from both directions, and by the hard structures that fully compartmentalize the beach and preventing the sediment from leaving the system (Figs. 1B, 7).

Given the short distance and the same setting as Portonovo, Sirolo beach showed a behaviour which was similar to the other beach. However, at Sirolo, given the greater beach width and length, the morphological changes are less evident than in Portonovo. Likewise in Portonovo, a significant amount of sediment moves alongshore according to the bimodal storm direction through the same mechanism of shoreline rotation observed at Sirolo by Harley et al. (2014). The larger accommodation space for sediment deposition also provides Sirolo beach with a lesser recovery need: even though really energetic storms did not occur during the survey period, Sirolo showed the most stable arrangement of the shoreline and beach topography. The summer period, without storms and dominated by southeasterly winds, brought a natural readjustment of the beach configuration with mild erosion of the central part of the beach and subtle accretion of the beach edges (Fig. 6 C3, D3). The traditional model for beach morphodynamics, assuming that beaches are eroded during high wave energy in "winter" conditions and recover under milder, "summer" conditions (Naylor et al., 2017) seems to be perfectly suitable for describing the behaviour of Sirolo beach (Fig. 7). The behaviour of Marina di Pisa is instead different from the two Adriatic sites: here the shoreline rotation does not
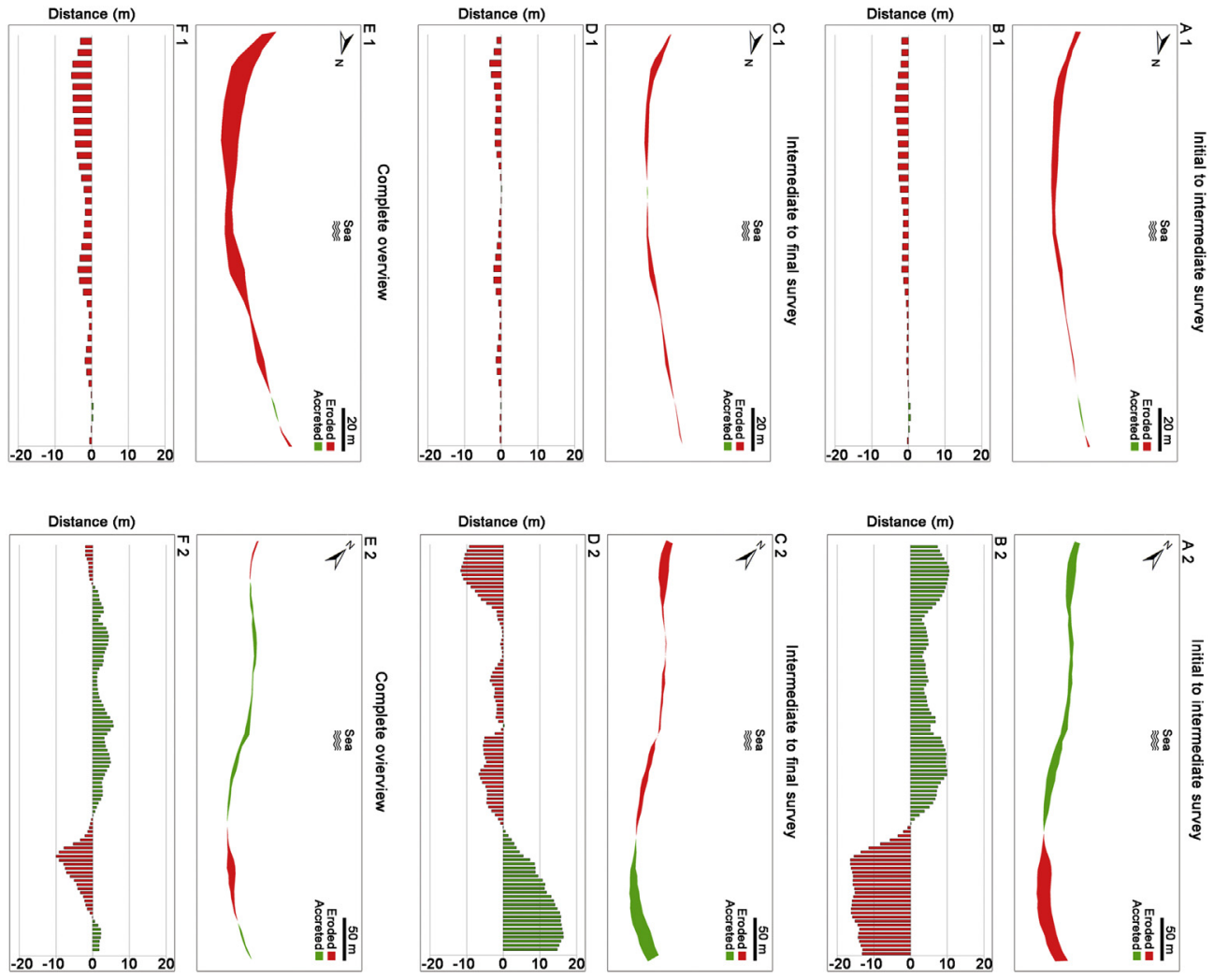

Distance (m)
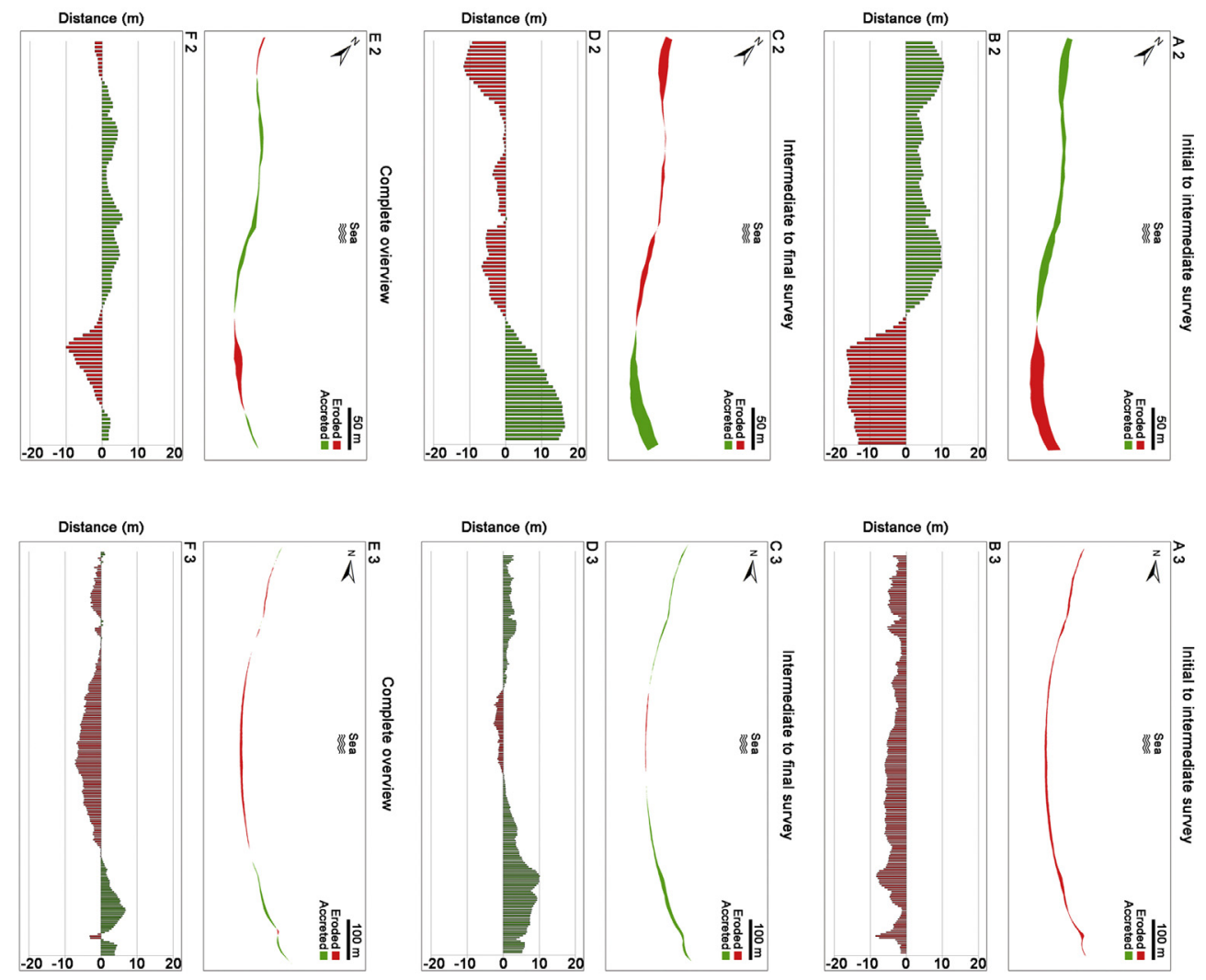

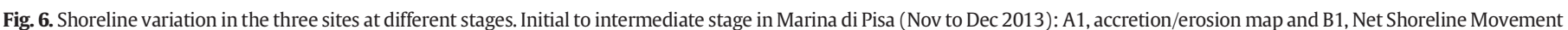

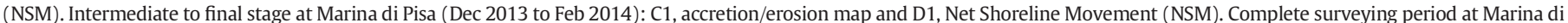

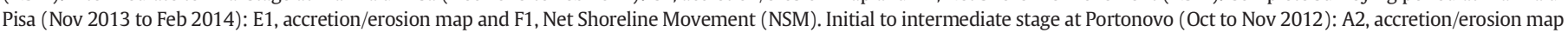

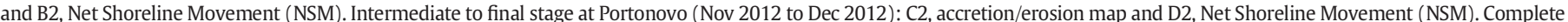

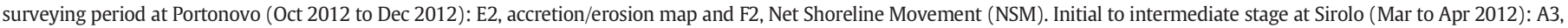

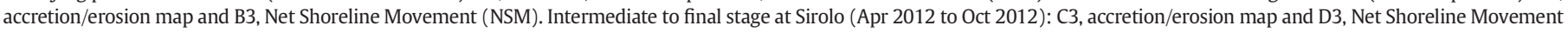
(NSM). Complete surveying period at Sirolo (Mar 2012 to Oct 2012): E3, accretion/erosion map and F3, Net Shoreline Movement (NSM). 
occur even after the major storms. In fact, the sediments at Marina di Pisa move preferentially cross-shore and mainly deposit on the upper part of the beach. The larger diameter of pebbles at Marina di Pisa makes the beach system less dynamic if compared to the two Adriatic sites. The sediment size seems to play an important role, especially when it is not native to the beach, as for the "engineered" beach of Marina di Pisa. On a native, pure gravel pocket beach, Han et al. (2017) found a good recovery of the profile and shoreline position, underlining the effectiveness of a gravel barrier as a coastal protection feature from erosion during storms. The storm response of a beach like Marina di Pisa is instead more complicated: here the gravel fraction is non-native and it is even two orders of magnitude greater than the native sand. Furthermore, the nourishment material used at Marina di Pisa (marble) is characterized by the loss of a high percentage of its volume due to particle abrasion, as highlighted by Bertoni et al. (2016). The authors found that in one year the most dynamic portion of the beach can lose up to $50 \%$ of the original fill volume due to sediment abrasion. Marina di Pisa, being a composite mixed beach (according to Jennings and Shulmeister, 2002; Fig. 7) due to the net separation between coarse pebbles of the nourishment and the native sand, likely suffers from highest wearing of the gravel fraction due to the poor intermixing between the two sediment sizes. Thus, the term composite mixed beach, even though following the Jennings and Shulmeister (2002) classification is the type that most resembles the Marina di Pisa beach configuration, it is probably misleading on this case, considering the beach behaviour. Here the beach acts like a pure gravel beach, with extremely low recovery capability after storms, since the active part that responds to the storms is mainly the non-native gravel fraction. As already pointed out by Cammelli et al. (2006), the net separation between sand and gravel at Marina di Pisa occurs on the submerged beach profile $(2 \mathrm{~m}$ below the m.s.l. which here corresponds to the position of the beach step). On the contrary, Jennings and Shulmeister (2002) define the composite type of beach as a mixed beach where the clear separation between sand and gravel occurs on the low tide terrace. Thus there seems to be a disagreement between the most widely used beach classifications and case studies in the Mediterranean. Cammelli et al. (2006) also pointed out that the gravel fraction here is definitely not intermixed with sand throughout the entire profile, especially on the upper backshore, so even the use of mixed sand and gravel beach type definition seems unrealistic. Here it is necessary to recall how this beach has become of mixed sediment nature because of human action, which introduced the coarse gravel fraction that was absent before the nourishments. On the other hand, the nourishment projects undertaken in Portonovo and Sirolo, which were naturally mixed sand and gravel beaches according to Jennings and Shulmeister (2002), respected the compatibility of fill material with the native sediment. The nourishment kept the dynamic characteristics of the entire sediment body untouched, allowing for a fast beach recovery after storms (Fig. 7). Bergillos et al. (2016) already suggested that mixed sand and gravel beaches recover faster from storm erosion than sandy beaches, even if it seems that their response to different energy conditions seems far from being properly understood. One of the points that still needs attention is the understanding of beach response to storms and sequences of storms, also in terms of climate change. Bramato et al. (2012) found that mild to low-energy and moderate sea states are able to generate recovery of mixed beaches from eroded states, likewise it was experienced in the last period in Sirolo. Most importantly, the previous authors also agreed that storms, quite unexpectedly, can accelerate the beach recovery, as clearly seen at Portonovo in this paper and at Sirolo by Harley et al. (2014). Over a two-year period of topographic measurements on Portonovo beach, Grottoli (2015) estimated a total gain of $3790 \mathrm{~m}^{3}$ in terms of emerged beach volume. Thus, medium- to long-term topographic measurements are always recommended to better understand the behaviour of mixed and coarse-grained beaches, given their intrinsic complexity. This should become a protocol for post-assessment of nourishments.

\section{Conclusions}

The current paper examined the morphological response to storms of three Mediterranean coarse-grained beaches. Analyses of beach topography and shoreline variations allowed us to discriminate the impact and recovery patterns on the three case study sites. The combined effect of storm direction (that is linked to the beach orientation) and the lack of accommodation space for sediment due to the onshore physical delimitations are the main reasons for the high variation
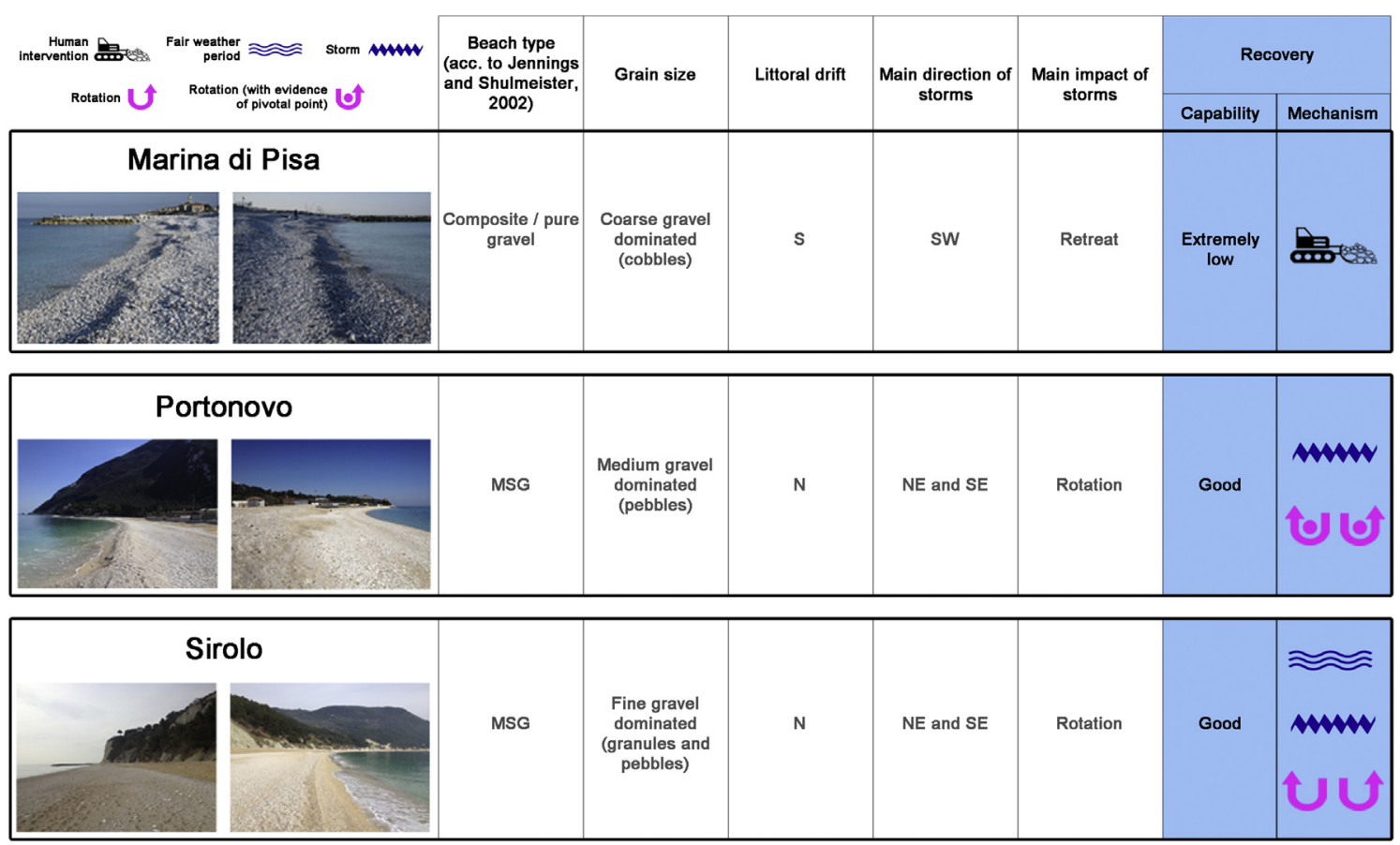

Fig. 7. Simplified scheme of storm response and recovery capability of the three sites. 
of beach morphological response (i.e. shoreline rotation or excessive sediment accumulation on the upper backshore). The lack of accommodation space observed here may have implications for the study of similar beaches in urbanized areas as well as embayed beaches at the base of cliffs. Greater morphological variations do not imply a slower recovery of beach topography and shoreline position. Post-storm recovery can be extremely fast, and contrasting storm directions can have alternate erosional/depositional roles due to shoreline rotation. The difference between the fill and the native material in term of grain size is a crucial characteristic in controlling the dynamics of the beach body in terms of storm response. Further studies are needed on grain abrasion processes of mixed beaches to better estimate the volume variations over time of the beach body. Mixed sand and gravel beaches are affected by impressive morphological variations (storm berms, erosive scarps, shoreline retreat-advance, sediment accumulations) that after an erosive event can be completely recomposed when the beaches experience the effects of a bimodal and opposite direction of storms. As seen at Portonovo, which experienced the highest morphological changes in the shortest time, a fast recovery of the beach configuration can occur thanks to the directional switching of subsequent storms of comparable energy. Marina di Pisa did not show any shoreline rotation. Here it is very unlikely that the beach can return to an "equilibrium" configuration after major storms, as groins laterally delimit the beach and there is no space for inland berm migration because of the presence of a coastal road. Only human intervention can redistribute the sediment accumulations over the profile. Portonovo and Sirolo showed a similar behaviour in terms of beach recovery and storm response. Given the frequent beach rotation, Portonovo acts like a pocket beach even though it is delimited by headlands like Sirolo, and its longshore delimitations increase the morphological effects of storms. Sirolo exhibited less evident morphological changes given its wider and longer beach that allows a more natural transport of sediments during storms and a mild recovery during fair weather periods. The widely used classification of Jennings and Shulmeister (2002) for gravel beaches must be adapted before it can be applied to artificially built coarse-grained beaches, accounting for the role of humans in changing the beach grain-size distribution.

\section{Acknowledgements}

We are thankful to Giannino Grottoli and Dr. Mitchell Harley for their support during the fieldwork in Portonovo and Sirolo. We also acknowledge ISPRA - Rete Ondametrica Nazionale and Regione Toscana Centro Funzionale Regionale for supplying offshore wave data. We finally thank the Regione Marche staff (Stefano Parlani and Giorgio Filomena) for the information about the replenishment works undertaken in the two Adriatic sites. Finally, we are grateful to the journal's anonymous reviewers and Editor-in-Chief for helping us to considerably improve the manuscript.

\section{References}

Almeida, L.P., Masselink, G., McCall, R., Russell, P., 2017. Storm overwash of a gravel barrier: field measurements and XBeach-G modelling. Coast. Eng. 120, 22-35.

Aminti, P., Cipriani, L.E., Pranzini, E., 2000. 'Back to the beach': converting seawalls into gravel beaches. Proc. of the First International Soft Shore Protection Conference, Patras, Greece, pp. 187-196.

Anfuso, G., Pranzini, E., Vitale, G., 2011. An integrated approach to coastal erosion problems in northern Tuscany (Italy): littoral morphological evolution and cell distribution. Geomorphology 129, 204-214

Armaroli, C., Ciavola, P., Perini, L., Calabrese, L., Lorito, S., Valentini, A., Masina, M., 2012 Critical storm thresholds for significant morphological changes and damage along the Emilia-Romagna coastline, Italy. Geomorphology 143-144, 34-51.

Austin, M.J., Buscombe, D., 2008. Morphological change and sediment dynamics of the beach step on a macrotidal gravel beach. Mar. Geol. 249 (3-4), 167-183.

Backstrom, J.T., Jackson, D.W.T., Cooper, J.A.G., Malvarez, G.C., 2008. Storm-driven shoreface morphodynamics on a low-wave energy delta: the role of nearshore topography and shoreline orientation. J. Coast. Res. 24, 1379-1387.

Bencivenga, M., Nardone, G., Ruggiero, F., Calore, D., 2012. The Italian data buoy network (RON). Proc. Advances in Fluid Mechanics IX, pp. 321-332.
Bergillos, R., Ortega-Sánchez, M., Masselink, G., Losada, M., 2016. Morpho-sedimentary dynamics of a micro-tidal mixed sand and gravel beach, Playa Granada, southern Spain. Mar. Geol. 379, 28-38.

Bertoni, D., Sarti, G., 2011a. On the profile evolution of three artificial pebble beaches at Marina di Pisa, Italy. Geomorphology 130, 244-254.

Bertoni, D., Sarti, G., 2011b. Grain size characterization of modern and ancient dunes within a dune field along the Pisan Coast (Tuscany, Italy). Atti Soc. Tosc. Sci. Nat. Mem. Ser. A. 116, 11-16.

Bertoni, D., Sarti, G., Benelli, G., Pozzebon, A., Ragueseo, G., 2010. Radio Frequency Identification (RFID) technology applied to the definition of underwater and subaerial coarse sediment movement. Sediment. Geol. 228, 140-150.

Bertoni, D., Sarti, G., Benelli, G., Pozzebon, A., 2012. In situ abrasion of marked pebbles on two coarse-clastic beaches (Marina di Pisa, Italy). Ital. J. Geosci. 131 (2), 205-214.

Bertoni, D., Grottoli, E., Ciavola, P., Sarti, G., Benelli, G., Pozzebon, A., 2013. On the displacement of marked pebbles on two coarse-clastic beaches during short fair-weather periods (Marina di Pisa and Portonovo, Italy). Geomar. Lett. 33, 463-476.

Bertoni, D., Sarti, G., Grottoli, E., Ciavola, P., Pozzebon, A., Domokos, G., Novák-Szabó, T., 2016. Impressive abrasion rates of marked pebbles on a coarse-clastic beach within a 13-month timespan. Mar. Geol. 381, 175-180.

Bluck, B.J., 2011. Structure of gravel beaches and their relationship to tidal range. Sedimentology 58, 994-1006.

Bramato, S., Ortega-Sánchez, M., Mans, C., Losada, M.A., 2012. Natural recovery of a mixed sand and gravel beach after a sequence of a short duration storm and moderate sea states. J. Coast. Res. 28, 89-101.

Bray, M.J., Hooke, J.M., 1997. Prediction of coastal cliff erosion with accelerating sea-level rise. J. Coast. Res. 13, 453-467.

Buscombe, D., Masselink, G., 2006. Concepts in gravel dynamics. Earth Sci. Rev. 79, $33-52$.

Cammelli, C., Jackson, N.L., Nordstrom, K.F., Pranzini, E., 2006. Assessment of a gravel nourishment project fronting a seawall at Marina di Pisa, Italy. J. Coast. Res. SI 39, $770-775$.

Chen, B., Stephenson, W., 2015. Measuring pebble abrasion on a mixed sand and gravel beach using abrasion baskets. Geomorphology 248, 24-32.

Cipriani, L.E., Ferri, S., Iannotta, P., Paolieri, F., Pranzini, E., 2001. Morfologia e dinamica dei sedimenti del litorale della Toscana settentrionale. Stud. Costieri 4, 119-156.

Colantoni, P., Mencucci, D., Baldelli, G., 2003. Idrologia e idraulica costiere processi litorali attuali e deposizione dei sedimenti. In: Coccioni, R. (Ed.), Verso la gestione integrata della costa del Monte San Bartolo: risultati di un progetto pilota. Quaderni del Centro di Geobiologia dell'Università degli Studi di Urbino, Urbania, pp. 15-37.

Dickson, M.E., Walkden, M.J.A., Hall, J.W., 2007. Systemic impacts of climate change on an eroding coastal region over the twenty-first century. Clim. Chang. 84, 141-166.

Dickson, M.E., Kench, P.S., Kantor, M.S., 2011. Longshore transport of cobbles on a mixed sand and gravel beach, southern Hawke Bay, New Zealand. Mar. Geol. 287, 31-42.

Dolan, R., Davis, R.E., 1992. An intensity scale for Atlantic coast northeast storms. J. Coast. Res. 8, 840-853.

Ellis, J.T., Cappietti, L., 2013. Storm-driven hydrodynamic and sedimentological impacts to an engineered coast. J. Coast. Res. SI 65, 1461-1466.

Ferreira, O., 2005. Storm groups versus extreme single storms: predicted erosion and management consequences. J. Coast. Res. 42, 221-227.

Gandolfi, G., Paganelli, L., 1975. Il litorale pisano-versiliese (Area campione Alto Tirreno). Boll. Soc. Geol. Ital. 94, 1273-1295.

Grottoli, E., 2015. Sediment Transport and Morphodynamics of Mixed Beaches: Case Studies of Two Mediterranean Sites. (PhD thesis in Earth Sciences). University of Ferrara.

Grottoli, E., Bertoni, D., Ciavola, P., Pozzebon, A., 2015. Short term displacements of marked pebbles in the swash zone: focus on particle shape and size. Mar. Geol. 367, 143-158.

Han, M., Yang, D.Y., Yu, J., Kim, J.W., 2017. Typhoon impact on a pure gravel beach as assessed through gravel movement and topographic change at Yeocha Beach, South Coast of Korea. J. Coast. Res. 33 (4), 889-906.

Harley, M.D., Andriolo, U., Armaroli, C., Ciavola, P., 2014. Shoreline rotation and response to nourishment of a gravel embayed beach using a low-cost video monitoring technique: San Michele-Sassi Neri, Central Italy. J. Coast. Conserv. 18, 551-565.

Hay, A., Zedel, L., Stark, N., 2014. Sediment dynamics on a steep, megatidal, mixed sandgravel-cobble beach. Earth Surf. Dyn. 2, 443-453.

Ivamy, M.C., Kench, P.S., 2006. Hydrodynamics and morphological adjustment of a mixed sand and gravel beach, Torere, Bay of Plenty, New Zealand. Mar. Geol. 228, 137-152.

Jennings, R., Shulmeister, J., 2002. A field based classification scheme for gravel beaches. Mar. Geol. 186, 211-228.

Maddrell, R., 1996. Managed coastal retreat, reducing flood risks and protection costs, Dungeness Nuclear Power Station, UK. Coast. Eng. 28, 1-15.

Masselink, G., Hughes, M.G., 2003. Introduction to Coastal Processes and Geomorphology. Arnold, London.

Masselink, G., van Heteren, S., 2014. Response of wave-dominated and mixed-energy barriers to storms. Mar. Geol. 352, 321-347.

McCall, R., Masselink, G., Poate, T., Roelvink, J., Almeida, L., Davidson, M., Russell, P., 2014. Modelling storm hydrodynamics on gravel beaches with XBeach-G. Coast. Eng. 91, 231-250.

McCall, R., Masselink, G., Poate, T., Roelvink, J., Almeida, L., 2015. Modelling the morphodynamics of gravel beaches during storms with XBeach-G. Coast. Eng. 103, $52-66$.

Mendoza, E., Jimenez, J., Mateo, J., 2011. A coastal storms intensity scale for the Catalan sea (NW Mediterranean). Nat. Hazards Earth Syst. Sci. 11, 2453-2462.

Molinelli, M., 2014. Caratterizzazione geomorfologica e valutazione di rischio di sversamento di idrocarburi nelle spiagge di Portonovo e Sirolo. (Master thesis in Geological Sciences). University of Ferrara. 
Morton, R., Sallenger, A., 2003. Morphological impacts of extreme storms on sandy beaches and barriers. J. Coast. Res. 19 (3), 560-573.

Naylor, L.A., Spencer, T., Lane, S.N., Darby, S.E., Magilligan, F.J., Macklin, M.G., Möller, I., 2017. Stormy geomorphology: geomorphic contributions in an age of climate extremes. Earth Surf. Process. Landf. 42, 166-190.

Nordstrom, K.F., Pranzini, E., Jackson, N.L., Coli, M., 2008. The marble beaches of Tuscany. Geogr. Rev. 98, 280-300.

Poate, T., Masselink, G., Davidson, M., McCall, R., Russell, P., Turner, I., 2013. High frequency in-situ field measurements of morphological response on a fine gravel beach during energetic wave conditions. Mar. Geol. 342, 1-13.

Regione Marche, 2005. Studi, indagini, modelli matematici finalizzati alla redazione del piano di difesa della costa. Boll. Ufficiale Regione Marche 21, 4199-4675.

Roberts, T.M., Wang, P., Puleo, J.A., 2013. Storm-driven cyclic beach morphodynamics of a mixed sand and gravel beach along the Mid-Atlantic Coast, USA. Mar. Geol. 346, 403-421.

Sammut, S., Gauci, R., Drago, A., Gauci, A., Azzopardi, J., 2017. Pocket beach sediment: a field investigation of the geodynamic processes of coarse-clastic beaches on the Maltese Islands (Central Mediterranean). Mar. Geol. 387, 58-73.
Scott, T., Masselink, G., O'Hare, T., Saulter, A., Poate, T., Russell, P., Davidson, M., Conley, D., 2016. The extreme 2013/2014 winter storms: beach recovery along the southwest coast of England. Mar. Geol. 382, 224-241.

Sénéchal, N., Castelle, B., Bryan, K.R., 2017. Storm clustering and beach response. In: Ciavola, P., Coco, G. (Eds.), Coastal Storms: Processes and Impacts. Wiley, Chichester, UK, pp. 151-174.

Short, A.D., Masselink, G., 1999. Embayed and structurally controlled beaches. In: Short A.D. (Ed.), Handbook of Beach and Shoreface Morphodynamics. Wiley, Chichester, UK, pp. 230-250.

Thieler, E.R., Himmelstoss, E.A., Zichichi, J.L., Ergul, A., 2009. Digital Shoreline Analysis System (DSAS) version 4.0 - an ArcGIS extension for calculating shoreline change. U.S Geological Survey Open-File Report 2008-1278.

Turki, I., Medina, R., Gonzalez, M., Coco, G., 2013. Natural variability of shoreline position: observations at three pocket beaches. Mar. Geol. 338, 76-89.

Zhang, K., Douglas, B.C., Leatherman, S.P., 2004. Global warming and coastal erosion. Clim. Chang. 64, 41-58. 